\title{
Writing (in) the Syncope
}

Charlotte Wegener ${ }^{1}$, Institut for Kommunikation og Psykologi, Aalborg Universitet

March 2020. In my enforced seclusion due to the COVID-19 outbreak and societal shutdown, I work in intervals of no more than fifteen minutes. Often less. I have longed for a break from a fast-paced academic life, for solitude, for slower rhythms. I now find myself restlessly shifting between checking up on family and friends, taking care of worried students, reading the news feed on my phone. Connected like never before and trying to figure out how to write - let alone what to write.

I am writing at the dinner table; from the kitchen comes the remote sound of my daughter's high-school teacher instructing a group exercise over the laptop speaker. I attempt to write about rhythm, and I wonder how arrhythmia on this scale affects my own writing and the way I can - and want to - teach writing.

Lefebvre puts forward the idea of 'rhythmanalysis' as an embodied endeavour and stresses the researcher's attention to inner and outer rhythms. He says that in order to grasp rhythms, it is necessary to get partly outside them, be it through illness or a technique (Lefebvre, 1992). We do not need a technique right now; illness is right on our doorstep. Writing about rhythmanalysis of education, Alhadeff-Jones (2016) refers to Sauvanet's use of the term 'syncope'. It is close to words such as interval, kairos, crisis or leap. These words refer to phenomena that can have freeing effects, he says, because they address a rupture that renews a rhythmic experience. It is an intense experience that requires 'the ability to sort, separate, organize, decide and judge what has to be done' (p. 168). Having the capacity to experience or provoke a syncope (e.g. break, crisis or kairos) is an opportunity to reinvent oneself and feel free because you renew a rhythm that would otherwise have been too monotonous, says Alhadeff-Jones.

In this syncope, in which the arrhythmic heartbeat of the world reveals itself to me, in a feeling of excessive seclusion and connection, all I can do is write. So, I write.

According to science fiction author, essayist and poet Ursula K. Le Guin, learning takes time and experience needs to compost:

'Compost is stuff, junk, garbage, anything, that's turned into dirt by sitting around a while. It involves silence, darkness, time, and patience. From compost, whole gardens grow.' (Le Guin, 2016, p. 110)

Le Guin's gardens are stories:

'Like a poem, a story says what it has to say in the only way it can be said, and that is the exact words of the story itself. Which is why the words are so important, why it takes so long to learn how to get the words right. Why you need silence, darkness, time, patience, and a real, solid knowledge of English vocabulary and grammar.' (Le Guin, 2016, p. 110)

\footnotetext{
1 Contact: cw@hum.aau.dk
} 
Le Guin makes the distinction between imagination and wishful thinking - a difference that is important to know both in writing and in life, she says. Wishful thinking is detached from reality; it is self-indulgent, false and even dangerous. Imagination, on the other hand, starts from reality and, even in its wildest flights, returns to reality to enrich it.

I wonder if this is in accordance with Lefebvre's ambition of creating a general theory of rhythms 'from particles to galaxies', attempting to separate as little as possible the scientific from the poetic (Lefebvre, 1992).

I take the opportunity to experience silence, darkness, emptiness, and practise patience. I let scientific and poetic words assist me towards a story. Others do it otherwise. Many do not have that luxury. Patience and poetry are not options for the Asian immigrant workers trapped in Moscow transit airports with expired work permits, the inhabitants of the Cape Town townships who share one water tap with a hundred neighbours, or the New Delhi citizens desperately trying to buy food in the four-hour window from the political announcement of the curfew until it takes effect and you risk being beaten up.

In this syncope, I watch all this. I have never before watched any news about the conditions of Asian immigrant workers in Russia, access to tap water in South African townships or the status of the food supply in India. It is not that I didn't know about these and other disasters around the world, but I chose not to remind myself. Now, I need to know. I also need to know the writing of Le Guin and her insistence that we never give up imagination. Stories that invoke hope are not wishful thinking, she says; it is not stories that deny pain. What we all need to learn every day is to nurture imagination and seek to contribute whatever we have in an effort to continually build new grounds for hope.

I have finished writing, and on my way to bed I remember it's my nephew's birthday. He turns 27 today, and I search for his name in my Contacts. It's been a while. His last note to me is an image of their three-month ultrasound scan. I send my love and congratulations and look at the image once more before I go to sleep. We know now that it's a girl. She will enter this world in July, and yet she is already here.

I can't wait.

\section{References}

Alhadeff-Jones, M. (2016). Time and the Rhythms of Emancipatory Education: Rethinking the Temporal Complexity of Self and Society. Oxon: Routledge.

Le Guin, U. K. (2016). Words Are My Matter: Writings About Life and Books, 2000-2016 with A Journal of a Writer's Week. Easthampton, MA: Small Beer Press.

Lefebvre, H. (1992). Rhythmanalysis: Space, Time and Everyday Life. London: Bloomsbury Academic. 


\section{Betingelser for brug af denne artikel}

Denne artikel er omfattet af ophavsretsloven, og der må citeres fra den.

Følgende betingelser skal dog være opfyldt:

- Citatet skal være i overensstemmelse med "god skik"

- Der må kun citeres „i det omfang, som betinges af formålet"

- Ophavsmanden til teksten skal krediteres, og kilden skal angives ift. ovenstående bibliografiske oplysninger 